\title{
THE EFFECT OF CUSTOMER EMPOWERMENT AND CUSTOMER ENGAGEMENT ON MARKETING PERFORMANCE: THE MEDIATING EFFECT OF BRAND COMMUNITY MEMBERSHIP
}

\author{
Anber Abraheem MOHAMMAD \\ Marketing Department, Petra University, Jordan, P.O. Box: 961343, Amman 11196, Jordan
}

Received 24 November 2019; accepted 30 December 2019

\begin{abstract}
This study aimed at examining the mediating role of brand Community membership on the effect of customer empowerment and customer engagement on marketing performance. The population of the study contained students of universities in the North Region of Jordan. A total of 1320 questionnaires were administered to sample members, and 895 questionnaires were returned completed. Data analysis indicated a significant partial mediation of brand community in the effect of customer empowerment on customer satisfaction but not in the effect of customer engagement and customer loyalty. Interestingly, the results confirmed that employee engagement is more important for organisations to ensure customer loyalty. The effect of customer empowerment on customer satisfaction was mediated by the customer's membership to the brand community. Thereupon, organisations should ensure put their customers' engagement as a priority. Further research is required to investigate the predictability of both customer satisfaction and engagement using different samples from several settings.
\end{abstract}

Keywords: customer empowerment, customer satisfaction, brand community, customer engagement, customer loyalty.

JEL Classification: M31.

\section{Introduction}

Despite what has been said about empowerment, whether employee empowerment or customer empowerment, this concept does not necessarily result in the desired benefits. Customers are empowered to make them more involved to get their feedback on products (S. Bansal \& D. Bansal, 2018) or to give them control over some aspects of a brand (Cova \& Pace, 2006). An advanced practice of customer empowerment refers to the transfer of brand decisions to customers themselves (Pranic \& Roehl, 2012). Recent evidence on the importance of customer empowerment was found by Berraies and Hamouda (2018) who revealed a significant impact of customer empowerment on the bank's financial performance. That impact was significantly mediated by customer satisfaction. Furthermore, the positive effect of customer empowerment on customer satisfaction was detected in the literature (Fuchs \& Schreier, 2011; O’Cass \& Viet Ngo, 2011).

A relatively new concept that found its way in marketing thinking is the concept of brand community. Muniz and O'guinn (2001) introduced this concept to describe social associations among people who admire the same brand. The main theme, according to the authors, of this specialised community, is the central focus on the brand. According to Cova and Pace (2006), one of the most important features of this community is brand loyalty. They termed the concept as a new style of customer empowerment. Bagozz and Dholakia (2006) defined brand community as a group of customer who shares a social identity in relation to a specific brand.

Customer engagement, further, refers to many aspects of customer's relationships with an organisation or a brand. Definitions of customer engagement presented by Brodie et al. (2013) disclosed that this concept combines customers' physical, cognitive and emotional aspects into their relationships with the organisation by which they motivated to participate in an effective as well interactive manner. Gummerus et al. (2012) used the concept of customer engagement to refer to customer behaviours related to the brand community such as brand community visits and using brand community activities. In contrast, this study followed a broader definition of customer engagement stated by van Doorn et al. (2010) who conceptualise this concept as motivation-based behaviours in which a customer go beyond purchase intention to participate in different activities

*Corresponding author. E-mail: mohammad197119@yahoo.com 
such as online reviewing, brand-oriented recommendations, and brand-directed suggestions.

Given the positive effect of customer engagement on customer loyalty (Bowden, 2009; Vivek, Beatty, \& Morgan, 2012), one may ask is there any role that brand community play in the relationship between customer engagement and customer loyalty? Referring to what was stated above on the relationship between customer empowerment and customer satisfaction, does brand community take part in the relationship between customer empowerment and customer satisfaction? To answer these two questions and to gain more understanding on the effects among customer empowerment, customer satisfaction, brand community, customer engagement, and customer loyalty, this study was carried out to examine these effects. The brand community was assumed to exhibit a meditational role in the effect of customer empowerment on customer satisfaction and in the effect of customer engagement on customer loyalty.

The present study aims to contribute to the understanding of the customer empowerment and customer engagement - marketing performance relationship in the presence of brand community membership by contributing with an additional perspective to the researchers' debate in the literature that claims different views for the relationship (Hoyer et al., 2010). The studies that do quantifiably study the effects of customer empowerment provide tentative support for its positive impacts but still leave much room for debate. Hence, most researches on the effect of customer empowerment and customer engagement on marketing performance have so far reported mixed results (Fuchs \& Schreier, 2011). Since several studies covered the relationship between customer empowerment, customer engagement and other variables, the researcher couldn't find big focus on the marketing performance as a major dependent variable in the literature, and it has received relatively little empirical attention in the literature, especially when introducing brand community membership as a mediating variable. Even recent researchers, where tackling marketing performance among other outcomes with no focus on the direct customer empowerment, customer engagement - marketing performance relationship. Accordingly, several researchers have voiced the need to address these shortcomings in prior research (Hoyer et al., 2010). This can be considered as a major contribution to this research. Study rationale can be justified in terms of little research taken place to examine customer empowerment, engagement, satisfaction and loyalty in a digital brand community context (Tsiotsou, 2016; Hsieh, Tseng, \& Lee, 2018).

\section{Literature review and hypotheses development}

\subsection{Customer empowerment and customer satisfaction}

Customer empowerment (CE) was defined in the literature as customer's feedback, control or transfer of power.
S. Bansal and D. Bansal (2018) defined CE as a way in which customers can provide feedback on the organisation's goods or services. Cova and Pace (2006) characterised CE as customer's control over brand-related variables just as the meaning of the brand. Giving a customer the control in this way means that the organisation selects to transfer the power of brand-related decisions from an external party, i.e., employees to the customer of the products (Pranic \& Roehl, 2012). Customer satisfaction can be increased using information collected on customers' needs and expectations, as well as meeting these needs along with introducing new services that add value for customers (Öberg, 2011 as cited in Papaioannou et al., 2018). Therefore, instead of collecting and analysing customers' information to identify and meet their needs, the organisation may empower its customers because they are the best who able to understand their needs and determine the best way to meet these needs. In a recent study conducted by Berraies and Hamouda (2018), customer empowerment was found to be a significant predictor of banks' financial performance through both customer satisfaction and innovation. Based on the literature mentioned above, the following hypothesis was suggested:

H1: Customer empowerment exhibits a statistically significant impact on customer satisfaction.

\subsection{Customer empowerment and brand community}

A key reason behind customer empowerment is to increase customer value by giving him access to express his wants (Pires, Stanton, \& Rita, 2006). Following Ouschan, Sweeney, and Johnson (2006) who studied customer empowerment in healthcare settings, customer empowerment can be conceptualized using three major dimensions; customer control, customer participation, and organisation support. For the present study, a customer can practice these three dimensions through his identification to a brand community. That is, an empowered customer is encouraged to participate in the brand community to benefit from empowerment-related advantages. Utilising their power of empowerment, customer can use social media means to create a brand-related content via writing articles, reviews, publishing weblogs, or contribute to the brand through rating brands, participate in brand conversations, or provide comments on brand videos or other related items (Muntinga, Moorman, \& Smit, 2011). Therefore, it was hypothesized that:

H2: Customer empowerment exhibits a statistically significant impact on the brand community.

\subsection{Brand community and customer satisfaction}

The relationship between brand community and customer satisfaction can be explained through customer personal and emotional interactions, since these interactions induce significant outcomes such as customer satisfaction and loyalty (Bitner, Brown, \& Meuter, 2000). It was presumed in the current study that customer's participation 
in community brands will result in an increased level of their satisfaction. Customers actually gain different advantages from their participation in brand community just like to pursue their purposes to be satisfied.

H3: Brand community exhibits a statistically significant impact on customer satisfaction.

H4: Brand community mediates the effect of customer empowerment on customer satisfaction.

\subsection{Customer engagement and customer loyalty}

O'Brien and Toms (2010) defined customer engagement as a psychological process that results in customer loyalty. So et al. (2016) conducted a study to investigate the role of customer engagement in customer loyalty. Their results indicated that customer engagement could be regarded as one of the most valuable predictors of customer loyalty. In a study on customer engagement in social media, De Vries and Carlson (2014) found a positive relationship between customer engagement and customer loyalty. In a framework of customer engagement developed by Pansari and Kumar (2017), customer satisfaction and emotions were antecedents of customer engagement. Greve (2014) confirmed the moderating role played by customer engagement in the relationships between brand image and brand loyalty. Hollebeek (2011) illustrated that the enhancement of customer loyalty could be achieved through the enhancement of customer engagement. Based on these results, the following hypothesis was proposed:

H5: Customer engagement exhibits a statistically significant impact on customer loyalty.

\subsection{Customer engagement and brand community}

Brodie et al. (2013) determined five reasons that motivate customers to engage in brand communities. These reasons were: learning, sharing, advocating, socialising and co-developing. Constantin, Platon, and Orzan (2014) indicated that the first reason for customer engagement in a brand community is the need for information on which his consumption decisions are building (learning). A customer can also contribute to the community through his personal information (sharing), or his recommendations (advocating).

Furthermore, customer interactions with community members (socialising) and his contribution to organisational performance (co-developing) are two factors that call customers to engage in bran community. Therefore, the presence of these factors will result in customer engagement in the brand community. In the current study, customer engagement refers to a psychological state of a customer represented by an emotional bond to a brand. This state exists before the formation of the brand community. The question that the study seeks to answer here: does the psychological state of a customer who is engaged to brand, either offline or online, induce his participation in the brand community? This question can be answered after testing the following hypothesis:
H6: Customer engagement exhibits a statistically significant impact on the brand community.

\subsection{Brand community and brand loyalty}

In a study on brand experience and its effects on customer loyalty, Brakus, Schmitt, and Zarantonello (2009) revealed that brand experience was significantly associated with loyalty. Chan et al. (2014) indicated that customer engagement mediates the relationship between brand community characteristics and customer loyalty. In a study conducted by Tsiotsou (2013) on the role of tribal behaviour on brand loyalty, the brand community was positively related to customer loyalty. Briefly, the literature supports the significant effect of customer's participation in brand communities on their loyalty to brands (Brodie et al., 2013; Tsiotsou, 2016).

H7: brand community exhibits a statistically significant impact on customer loyalty.

H8: Brand community mediates the effect of customer engagement on customer loyalty.

\section{Research methodology}

\subsection{Research sample}

The population of the study contained all the students of private universities in Amman (Al-Ahliyya Amman University, Applied Science Private University, Amman Arab University, Middle East University, Philadelphia University, Isra University, Petra University, Al-Zaytoonah University of Jordan, Princess Sumaya University for Technology, and American University of Madaba). The total number of students at private universities at the time of the research was more than 45000 students. The sample size is an essential element of research design that significantly affects the validity and significance of the results of the study. The calculation of the sample size is necessary to assure the adequacy of the sample size to avoid Type II errors. The purposive sample of the study was restricted to 1320 students due to the inclusion criterion of a brand community membership. According to Algesheimer, Dholakia, and Herrmann (2005), customer brand identification can be identified via his membership in the community. The questionnaires, with instructions of how to complete them, were distributed to respondents by an interviewer. Subjects were asked to assess their perceptions of various items of different constructs. Assessments were based on A Five-point Likert scale ranging from "strongly disagree (1) to "strongly agree (5). To minimize possible response bias, instructions emphasised that the study focused only on their personal opinions. There were no right or wrong answers. After completion, the questionnaires were checked and collected by the interviewer. A total of 1320 questionnaires were administered to sample members and 895 questionnaires were returned complete, with a response rate of $67.8 \%$ 


\subsection{Research instrument}

Five items assessed customer empowerment developed based on the literature (Shankar, Cherrier, \& Canniford, 2006; Füller et al., 2009; Siano, Vollero, and Palazzo, 2011; Hudson \& Thal, 2013). Customer engagement was measured as one factor using five indicators adopted from previous studies such as customer's online comments, visits and likes on social media pages (Greve, 2014; Sarkar \& Sreejesh, 2014). Customer satisfaction was measured using five items following Al-Hawary and Al-Menhaly (2017) and Jaroensrisomboon (2018), Al-Hawary (2013), AlHawary and Al-smeran (2016); Al-Hawary et al. (2017); Alolayyan et al. (2018). The brand community was evaluated by five items adopted by from McAlexander, Schouten, and Koenig (2002) and Brakus et al. (2009). Finally, customer loyalty was measured by customer repurchase intention and word of mouth intention (Chan et al., 2014; Al-Hawary, 2013; Al-Hawary \& Harahsheh, 2014; Al-Hawary \& Hussien, 2016; Alshurideh et al., 2017).

\subsection{Reliability and validity}

The hypothesised model of the current study included five latent variables: customer empowerment, customer satisfaction, brand community, customer engagement, and customer loyalty. Twenty-five items were used to measure these variables. The measurement model of this study was tested by confirmatory factor analysis (CFA). Lavee, McCubbin, and Patterson (1985) stipulated that the aim of the measurement model is to specify latent variables regarding its observed variables. CFA was utilized to assess factor loadings $(\lambda)$. Moreover, CFA enables to measure instrument validity and reliability through Average Variance Extracted (AVE), McDonald's Omega Coefficient ( $\omega$ ), and Cronbach's Alpha ( $\alpha$ ) according to (Stacciarini \& Pace, 2017; Taber, 2018; Zainudin \& Subali, 2019). The results of the measurement model in Figure 1 was demonstrated in Table 1. Sarkar and Sreejesh (2014) stated that loadings should be higher than 0.5. Algesheimer et al. (2005) considered estimates of $(\omega)$ higher than 0.70 , estimates of (AVE) higher than 0.50 and $(\alpha)$ higher than 0.80 are acceptable to support instrument validity and reliability.

The results shown in Table 1 illustrated that these criteria were met for the current data. All factor loadings $(\lambda)$ were greater than 0.50 , ranging from 0.68 to 0.84 . Estimates McDonald's Omega Coefficient $(\omega)$ were greater than 0.70 , ranging from 0.85 to 0.89 . On the other hand, Cronbach's Alpha $(\alpha)$ were greater than 0.80 , ranging from

Table 1. Results of confirmatory factor analysis

\begin{tabular}{|c|c|c|c|c|c|c|c|}
\hline Factors & Indicators & $\lambda$ & $\lambda^{2}$ & $\varepsilon$ & AVE & $\omega$ & $\alpha$ \\
\hline \multirow{5}{*}{$\begin{array}{l}\text { Customer } \\
\text { empowerment }\end{array}$} & CEM1 & 0.83 & 0.689 & 0.311 & \multirow{5}{*}{0.604} & \multirow{5}{*}{0.883} & \multirow{5}{*}{0.877} \\
\hline & CEM2 & 0.81 & 0.656 & 0.344 & & & \\
\hline & CEM3 & 0.77 & 0.593 & 0.407 & & & \\
\hline & CEM4 & 0.69 & 0.476 & 0.524 & & & \\
\hline & CEM5 & 0.78 & 0.608 & 0.392 & & & \\
\hline \multirow{5}{*}{$\begin{array}{l}\text { Customer } \\
\text { engagement }\end{array}$} & CENG1 & 0.79 & 0.624 & 0.376 & \multirow{5}{*}{0.639} & \multirow{5}{*}{0.898} & \multirow{5}{*}{0.891} \\
\hline & CENG2 & 0.83 & 0.689 & 0.311 & & & \\
\hline & CENG3 & 0.84 & 0.706 & 0.294 & & & \\
\hline & CENG4 & 0.71 & 0.504 & 0.496 & & & \\
\hline & CENG5 & 0.82 & 0.672 & 0.328 & & & \\
\hline \multirow{5}{*}{$\begin{array}{l}\text { Customer } \\
\text { satisfaction }\end{array}$} & CSAT1 & 0.77 & 0.593 & 0.407 & \multirow{5}{*}{0.593} & \multirow{5}{*}{0.879} & \multirow{5}{*}{0.868} \\
\hline & CSAT2 & 0.81 & 0.656 & 0.344 & & & \\
\hline & CSAT3 & 0.83 & 0.689 & 0.311 & & & \\
\hline & CSAT4 & 0.75 & 0.563 & 0.438 & & & \\
\hline & CSAT5 & 0.68 & 0.462 & 0.538 & & & \\
\hline \multirow{5}{*}{ Brand community } & BCOM1 & 0.80 & 0.640 & 0.360 & \multirow{5}{*}{0.573} & \multirow{5}{*}{0.870} & \multirow{5}{*}{0.864} \\
\hline & BCOM2 & 0.69 & 0.476 & 0.524 & & & \\
\hline & BCOM3 & 0.73 & 0.533 & 0.467 & & & \\
\hline & BCOM4 & 0.80 & 0.640 & 0.360 & & & \\
\hline & BCOM5 & 0.76 & 0.578 & 0.422 & & & \\
\hline \multirow{5}{*}{ Customer loyalty } & CLOY1 & 0.68 & 0.462 & 0.538 & \multirow{5}{*}{0.546} & \multirow{5}{*}{0.857} & \multirow{5}{*}{0.850} \\
\hline & CLOY2 & 0.71 & 0.504 & 0.496 & & & \\
\hline & CLOY3 & 0.76 & 0.578 & 0.422 & & & \\
\hline & CLOY4 & 0.80 & 0.640 & 0.360 & & & \\
\hline & CLOY5 & 0.74 & 0.548 & 0.452 & & & \\
\hline
\end{tabular}


0.85 to 0.89 . Moreover, AVE were greater than 0.50 , which mean that the instrument valid and reliable (Cheung, Chiu, \& Lee, 2011).

\subsection{Model Goodness-of-fit}

To test the model's goodness-of-fit, six indices (Aldousari \& Elsayed, 2018) were used: the minimum discrepancy (Chi-square/degrees of freedom), goodness of fit index (GFI), adjusted goodness of fit index (AGFI), root mean square residual (RMR), The comparative fit index(CFI), and root mean square error of approximation (RMSEA). The results shown in Table 2 symbolised that all values of goodness-of-fit indices were accepted since the cut-off values were achieved.

\subsection{Descriptive statistics, correlations and multicollinearity}

Descriptive statistics (means and standard deviations) indicated that customer satisfaction was moderately ranked first $(\mathrm{M}=3.57, \mathrm{SD}=1.02)$ followed by customer engagement $(\mathrm{M}=3.48, \mathrm{SD}=3.43)$, customer empowerment $(\mathrm{M}=$ $3.40, \mathrm{SD}=0.811)$, brand community $(\mathrm{M}=3.39, \mathrm{SD}=0.960)$
Table 2. Results of Goodness-of-fit indices

\begin{tabular}{|l|l|c|l|}
\hline \multicolumn{1}{|c|}{ Index } & \multicolumn{1}{c|}{ Criterion } & Estimate & \multicolumn{1}{c|}{ Result } \\
\hline CMIN/DF & CMIN/DF $<2-5$ & 2.510 & Sustained \\
\hline GFI & GFI $>0.90$ & 0.954 & Sustained \\
\hline AGFI & AGFI $>0.90$ & 0.934 & Sustained \\
\hline RMR & RMR $<0.1$ & 0.06 & Sustained \\
\hline CFI & CFI $>0.90$ & 0.930 & Sustained \\
\hline RMSEA & RMSEA $<0.08$ & 0.065 & Sustained \\
\hline
\end{tabular}

and customer loyalty $(\mathrm{M}=3.37, \mathrm{SD}=0.589)$. The results showed also that all constructs were significantly correlated, customer empowerment was significantly correlated to customer satisfaction $(\mathrm{r}=0.38, \mathrm{P}<0.01)$ and brand community $\left(r=0.41^{\star}\right)$, customer engagement was significantly associated to customer loyalty $(\mathrm{r}=0.44, \mathrm{P}<0.05)$ but not to brand community $(\mathrm{r}=0.12, \mathrm{P}>0.01)$. Brand community was significantly linked to both customer satisfaction and customer loyalty $(r=0.42$ and $0.32, \mathrm{P}<0.05)$ respectively. Furthermore, the results in Table 3 showen that independent variables are not have of multicollinearity problem through VIF which indicated the values less than 5 and tolerance which referred the values greater than 0.1 (Walliman, 2017).

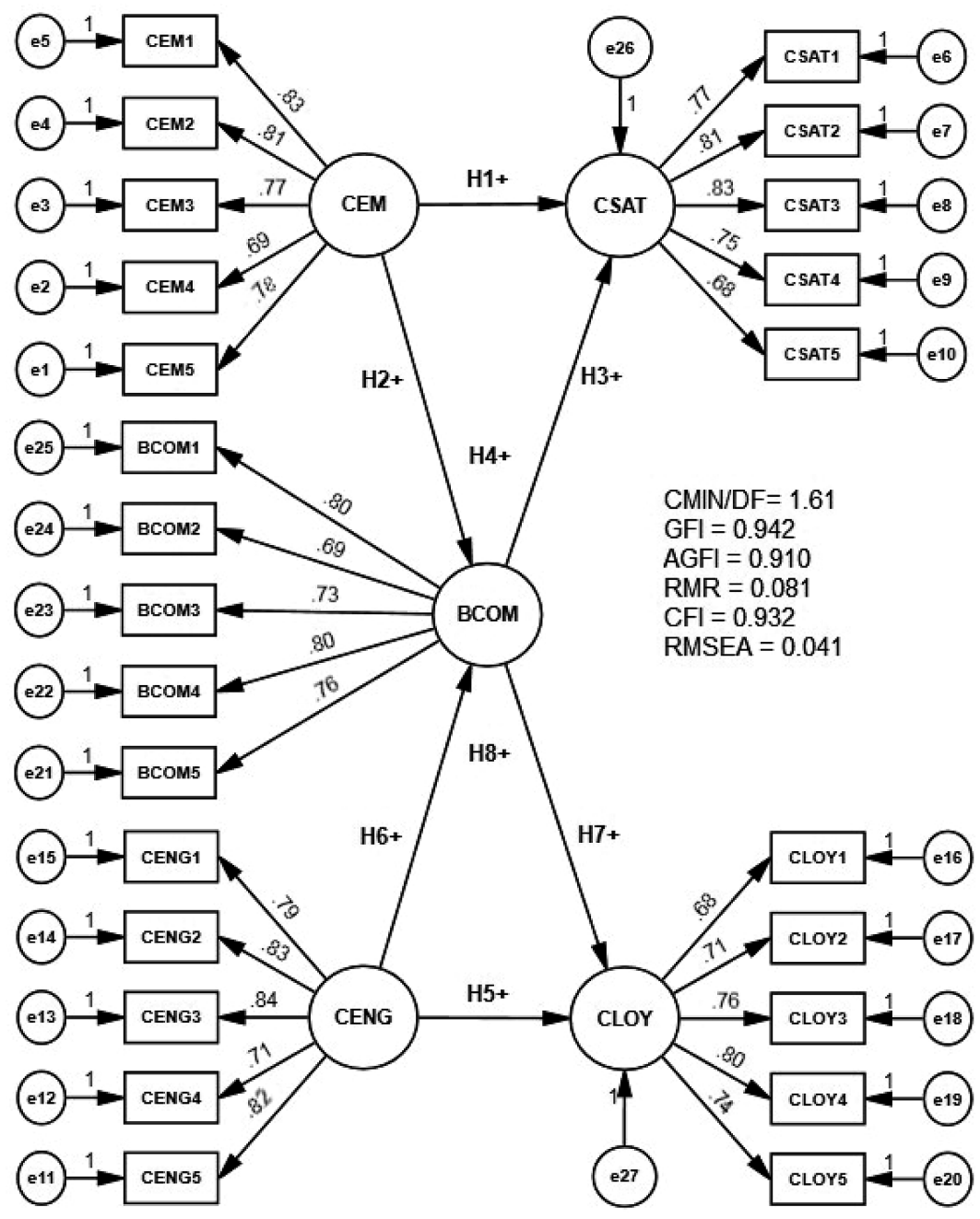

Figure 1. Research measurement model 
Table 3. Results of multicollinearity

\begin{tabular}{|l|c|c|c|}
\hline \multicolumn{1}{|c|}{ Independent Variables } & VIF & Tolerance & Result \\
\hline Customer Empowerment & 1.98 & 0.85 & Sustained \\
\hline Customer Engagement & 2.07 & 0.72 & Sustained \\
\hline
\end{tabular}

\subsection{Hypotheses testing}

Structural equation Modelling (SEM) was conducted in order to model errors that might found in the measurements used to assess the observed variables, to construct unobserved variables, and to model relationships among study variables (Chin, 1998). The mediation effect was defined as a link between antecedents and consequences (Nitzl et al., 2018). The results of hypotheses testing delineated in Table 4 as well as Figure 2 showed that customer empowerment was significantly and positively related to customer satisfaction $(\beta=0.190$, S.E. $=0.022$, $\mathrm{t}$-value $=$ $6.320, \mathrm{P}<0.05)$ and to brand community $(\beta=0.20$, S.E. $=$ $0.015, \mathrm{t}$-value $=4.981, \mathrm{P}<0.05)$. Customer engagement was significantly and positively related to customer loyalty $(B=0.24$, S.E. $=0.09$, $\mathrm{t}$-value $=6.111, \mathrm{P}<0.05)$ but

Table 4. Results of hypotheses testing

\begin{tabular}{|c|c|c|c|c|c|c|c|c|c|c|}
\hline \multicolumn{5}{|c|}{ Hypotheses } & B & S.E. & T & P & Results \\
\hline 1 & CEM & $\rightarrow$ & CSAT & & & 0.190 & 0.022 & 6.320 & $* * *$ & $\checkmark$ \\
\hline 2 & CEM & $\rightarrow$ & BCOM & & & 0.20 & 0.015 & 4.981 & $* * *$ & $\checkmark$ \\
\hline 3 & BCOM & $\rightarrow$ & CSAT & & & 0.21 & 0.10 & 5.160 & $\star * *$ & $\checkmark$ \\
\hline 4 & CSAT & $\rightarrow$ & BCOM & $\rightarrow$ & CSAT & - & - & - & - & $\checkmark$ \\
\hline 5 & CENG & $\rightarrow$ & CLOY & & & 0.24 & 0.09 & 6.111 & $\star * *$ & $\checkmark$ \\
\hline 6 & CENG & $\rightarrow$ & BCOM & & & 0.06 & 0.24 & 1.23 & 0.160 & $x$ \\
\hline 7 & BCOM & $\rightarrow$ & CLOY & & & 0.12 & 0.10 & 5.67 & $* * *$ & $\checkmark$ \\
\hline
\end{tabular}

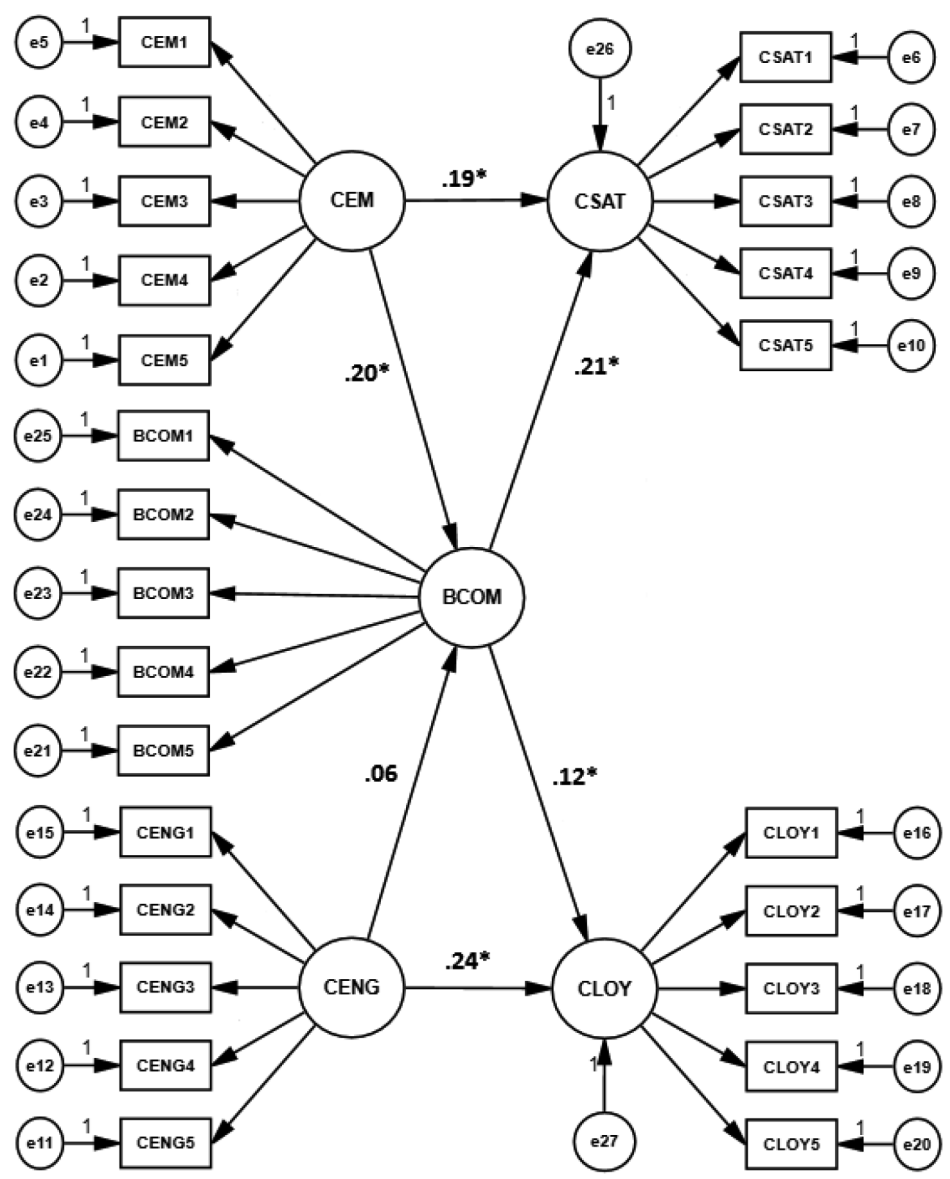

Figure 2. Research structural model 
not to brand community $(ß=0.06$, S.E. $=0.24$, $\mathrm{t}$-value $=$ $1.230, \mathrm{P}>0.05)$. Brand community was significantly and positively related to customer satisfaction $(\beta=0.21$, S.E. $=$ $0.10, \mathrm{t}$-value $=5.160, \mathrm{P}<0.05)$ and customer loyalty $(\beta=$ 0.12 , S.E. $=0.10, \mathrm{t}$-value $=5.670, \mathrm{P}<0.05)$.

Based on these findings, it was observed that the brand community mediated the effect of customer empowerment on customer satisfaction, while the brand community has no mediating role on the effect of customer engagement on customer loyalty.

\section{Discussion and conclusions}

Eight hypotheses were proposed in this study to investigate the effect of customer empowerment on customer satisfaction and brand community as well as the effect of customer engagement on customer loyalty. The brand community was assumed to affect customer satisfaction and customer engagement. Finally, the study suggested that the brand community mediates the effect of customer empowerment on customer satisfaction and the effect of customer engagement on customer loyalty. The results uncovered a significant effect of customer empowerment on customer satisfaction and brand community. On the other hand, it was revealed that customer engagement has a significant effect on customer loyalty and has no significant effect on the brand community. Brand community when examined with customer satisfaction and customer engagement, was found to be significantly and positively related to both customer satisfaction and customer loyalty. Interestingly, the results illustrated that the same mediator, which is a brand community, exhibited a mediating role on the effect of customer empowerment on customer satisfaction but did not play the same role on the effect of customer engagement on customer empowerment.

About the effect of customer empowerment on customer satisfaction, Öberg (2011, as cited in Papaioannou et al., 2018) indicated that organisations could increase customer satisfaction through asking them to show their needs and hence collecting the information provided by customers to meet their needs. Pires et al. (2006) stated that the main purpose of customer empower is to enhance customer satisfaction. On the other hand, the empowered customer is encouraged to participate in the brand community (Ouschan et al., 2006) using social media to rate brands (Muntinga et al., 2011). According to Bitner et al. (2000), the customer's emotional interactions with a brand can be used to explain their satisfaction and loyalty. De Vries and Carlson (2014) and So et al. (2016) considered customer engagement as a pivotal predictor of customer loyalty. Hollebeek (2011) indicated that an enhanced level of customer engagement results in more loyal customers. Concerning the non-significant relationship between customer loyalty and brand community found in this study, one can expect that none of the reasons that encourage individuals to participate in brand communities was achieved. For example, they as customers were not involved in advocating, learning or socializing using the brand community despite that they acknowledged that the membership of community brand leads to increased loyalty from their perspectives. In line with Constantin et al. (2014), another reason for the non-significant relationship between engagement and brand community is that customers have no opportunity to co-develop services or products using their thoughts.

\section{Implications for organisations and researchers}

Managers and researchers should note based on these results, that variables have different conceptualisations in accordance with the context in which these variables were studied. The brand community in this study has significant effects on customer satisfaction and customer loyalty. However, its mediating role on the effect of customer empowerment on customer satisfaction was supported while its mediating role on the effect of customer engagement on customer loyalty was rejected. Therefore, even though we have close constructs such as customer empowerment, customer engagement, customer satisfaction and customer loyalty, the effect of the mediator on the effect among these construct might be different.

\section{Limitations and future research directions}

The cross-sectional design of this study was a major limitation. The second limitation encountered was related to the variation of brand community membership among students. The mediating role of brand community in this study was tested between customer empowerment and customer satisfaction as well as between customer engagement and customer loyalty in the same model. To understand the mediating role of brand community on the effect of customer engagement on customer loyalty, both customer empowerment and customer satisfaction should be removed from the first model. In addition to that, the relationship between customer empowerment and customer engagement should be explored along with the relationship between customer empowerment and customer loyalty and the relationship between customer engagement and customer satisfaction.

\section{References}

Aldousari, A., \& Elsayed, I. (2018). Factors differentiating between concentric and sprinkled multiple-patronage shoppers in $\mathrm{Ku}-$ wait. Management \& Marketing, 13(1), 730-747.

https://doi.org/10.2478/mmcks-2018-0002

Algesheimer, R., Dholakia, U., \& Herrmann, A. (2005). The social influence of brand community: Evidence from European car clubs. Journal of Marketing, 69(3), 19-34.

https://doi.org/10.1509/jmkg.69.3.19.66363

Al-Hawary, S., \& Al-Menhaly, S. (2017). The quality of e-government services and its role on achieving beneficiaries satisfaction. Global Journal of Management And Business Research, 16(1), 1-11.

Al-Hawary, S. I. S. (2013). The role of perceived quality and satisfaction in explaining customer brand loyalty: mobile phone 
service in Jordan. International Journal of Business Innovation and Research, 7(4), 393-413.

Al-Hawary, S. I. S. (2013). The roles of perceived quality, trust, and satisfaction in predicting brand loyalty: the empirical research on automobile brands in Jordan market. International Journal of Business Excellence, 6(6), 656-686. https://doi.org/10.1504/IJBIR.2013.054848

Al-Hawary, S. I. S., \& Al-Smeran, W. F. (2016). Impact of electronic service quality on customers satisfaction of Islamic banks in Jordan. International Journal of Academic Research in Accounting, Finance and Management Sciences, 7(1), 170188. https://doi.org/10.6007/IJARAFMS/v7-i1/2613

Al-Hawary, S. I. S., \& Harahsheh, S. A. M. (2014). Factors affecting Jordanian consumer loyalty toward cellular phone brand. International Journal of Economics and Business Research, 7(3), 349-375. https://doi.org/10.1504/IJEBR.2014.060372

Al-Hawary, S. I. S., \& Hussien, A. J. (2016). The Impact of electronic banking services on the Customers Loyalty of Commercial Banks in Jordan. International Journal of Academic Research in Accounting, Finance and Management Sciences, 7(1), 50-63. https://doi.org/10.6007/IJARAFMS/v7-i1/2539

Al-Hawary, S. I. S., Batayneh, A. M., Mohammad A. I., \& Alsarahni, A. (2017). Supply chain flexibility aspects and their impact on customers' satisfaction of pharmaceutical industry in Jordan. International Journal of Business Performance and Supply Chain Modeling, 9(4), 326-343.

https://doi.org/10.1504/IJBPSCM.2017.091330

Alolayyan, M. N., Al-Hawary, S. I. S., Mohammad, A. A. S., \& Al-Nady, B. A. H. A. (2018). Banking service quality provided by commercial banks and customer satisfaction. A structural equation modelling approaches. International Journal of Productivity and Quality Management, 24(4), 543-565. https://doi.org/10.1504/IJPQM.2018.093454

Alshurideh, M. T., Al-Hawary, S. I. S., Batayneh, A. M. I., Mohammad A. I., \& Alkurdi, B. (2017). The impact of Islamic Banks' service quality perception on Jordanian customers loyalty. Journal of Management Research, 9(2), 139-159. https://doi.org/10.5296/jmr.v9i2.10664

Bansal, S., \& Bansal, D. (2018). Consumer engagement in electronic word-of-mouth on social networking sites. ELK Asia Pacific Journal of Marketing and Retail Management, 9(1), 1-29.

Berraies, S., \& Hamouda, M. (2018). Customer empowerment and firms' performance: The mediating effects of innovation and customer satisfaction. International Journal of Bank Marketing, 36(2), 2, 336-356. https://doi.org/10.1108/IJBM-10-2016-0150

Bitner, M., Brown, S., \& Meuter, M. (2000). Technology infusion in service encounters. Journal of the Academy of marketing Science, 28(1), 138-149.

https://doi.org/10.1177/0092070300281013

Bowden, J. (2009). The process of customer engagement: A conceptual framework. Journal of Marketing Theory and Practice, 17(1), 63-74. https://doi.org/10.2753/MTP1069-6679170105

Brakus, J., Schmitt, B., \& Zarantonello, L. (2009). Brand experience: what is it? How is it measured? Does it affect loyalty? Journal of Marketing, 73(3), 52-68. https://doi.org/10.1509/jmkg.73.3.52

Brodie, R., Ilic, A., Juric, B., \& Hollebeek, L. (2013). Consumer engagement in a virtual brand community: An exploratory analysis. Journal of Business Research, 66(1), 105-114. https://doi.org/10.1016/j.jbusres.2011.07.029

Chan, T., Zheng, X., Cheung, C., Lee, M., \& Lee, Z. (2014). Antecedents and consequences of customer engagement in online brand communities. Journal of Marketing Analytics, 2(2), 81-97. https://doi.org/10.1057/jma.2014.9
Cheung, C., Chiu, P., \& Lee, M. (2011). Online social networks: Why do students use facebook? Computers in Human Behavior, 27(4), 1337-1343. https://doi.org/10.1016/j.chb.2010.07.028

Chin, W. (1998). The partial least squares approach to structural equation modeling. Modern Methods for Business Research, 295(2), 295-336.

Constantin, V., Platon, O., \& Orzan, G. (2014). Brand community formation: A critical review. Annales Universitatis Apulensis Series Oeconomica, 16(2), 123-131.

Cova, B., \& Pace, S. (2006). Brand community of convenience products: new forms of customer empowerment - the case "my Nutella The Community". European Journal of Marketing, 40(9/10), 1087-1105. https://doi.org/10.1108/03090560610681023

De Vries, N., \& Carlson, J. (2014). Examining the drivers and brand performance implications of customer engagement with brands in the social media environment. Journal of Brand Management, 21(6), 495-515. https://doi.org/10.1057/bm.2014.18

Fuchs, C., \& Schreier, M. (2011). Customer empowerment in new product development. Journal of Product Innovation Management, 28(1), 17-32. https://doi.org/10.1111/j.1540-5885.2010.00778.x

Fuchs, C., \& Schreier, M. (2011). Customer empowerment in new product development. Journal of Product Innovation Management, 28(1), 17-32. https://doi.org/10.1111/j.1540-5885.2010.00778.x

Füller, J., MüHlbacher, H., Matzler, K., \& Jawecki, G. (2009). Consumer empowerment through internet-based co-creation. Journal of Management Information Systems, 26(3), 71-102. https://doi.org/10.2753/MIS0742-1222260303

Greve, G. (2014). The moderating effect of customer engagement on the brand image-brand loyalty relationship. Procedia-Social and Behavioral Sciences, 148, 203-210. https://doi.org/10.1016/j.sbspro.2014.07.035

Gummerus, J., Liljander, V., Weman, E., \& Pihlström, M. (2012). Customer engagement in a Facebook brand community. Management Research Review, 35(9), 857-877. https://doi.org/10.1108/01409171211256578

Hollebeek, L. (2011). Demystifying customer brand engagement: Exploring the loyalty nexus. Journal of Marketing Management, 27(7-8), 785-807. https://doi.org/10.1080/0267257X.2010.500132

Hoyer, W. D., Chandy, R., Dorotic, M., Krafft, M., \& Singh, S. S. (2010). Consumer cocreation in new product development. Journal of Service Research, 13(3), 283-296. https://doi.org/10.1177/1094670510375604

Hsieh, S. H., Tseng, T. H., \& Lee, C. T. (2018, January). Drivers of online brand community value creation: the role of psychological empowerment. In Proceedings of the 51st Hawaii International Conference on System Sciences. https://doi.org/10.24251/HICSS.2018.265

Hudson, S., \& Thal, K. (2013). The impact of social media on the consumer decision process: Implications for tourism marketing. Journal of Travel \& Tourism Marketing, 30(1-2), 156-160. https://doi.org/10.1080/10548408.2013.751276

Jaroensrisomboon, N. (2018). The relationship between perceived service quality, switching costs, customer satisfaction and customer loyalty. AU Journal of Management, 7(1), 24-31.

Lavee, Y., McCubbin, H., \& Patterson, J. (1985). The double ABCX model of family stress and adaptation: An empirical test by analysis of structural equations with latent variables. Journal of Marriage and the Family, 811-825. https://doi.org/10.2307/352326

McAlexander, J., Schouten, J., \& Koenig, H. (2002). Building brand community. Journal of Marketing, 66(1), 38-54.

https://doi.org/10.1509/jmkg.66.1.38.18451 
Muniz, A., \& O'guinn, T. (2001). Brand community. Journal of Consumer Research, 27(4), 412-432. https://doi.org/10.1086/319618

Muntinga, D., Moorman, M., \& Smit, E. (2011). Introducing COBRAs: Exploring motivations for brand-related social media use. International Journal of Advertising, 30(1), 13-46. https://doi.org/10.2501/IJA-30-1-013-046

Nitzl, C., Roldán, J., \& Cepeda, G. (2017). Mediation analyses in partial least squares structural equation modeling, helping researchers discuss more sophisticated models: an abstract. Marketing at the Confluence between Entertainment and Analytics. Developments in Marketing Science: Proceedings of the Academy of Marketing Science (pp. 693-693). Springer, Cham, https://doi.org/10.1007/978-3-319-47331-4_130

O'Brien, H., \& Toms, E. (2010). The development and evaluation of a survey to measure user engagement. Journal of the American Society for Information Science and Technology, 61(1), 50-69. https://doi.org/10.1002/asi.21229

Öberg, C. (2011). The core-customer concept. The Service Industries Journal, 31(16), 540-560. https://doi.org/10.1080/02642069.2010.511186

O’Cass, A., \& Viet Ngo, L. (2011). Achieving customer satisfaction in services firms via branding capability and customer empowerment. Journal of Services Marketing, 25(7), 489-496. https://doi. org/10.1108/08876041111173615

Ouschan, R., Sweeney, J., \& Johnson, L. (2006). Customer empowerment and relationship outcomes in healthcare consultations. European Journal of Marketing, 40(9/10), 1068-1086.

https://doi.org/10.1108/03090560610681014

Pansari, A., \& Kumar, V. (2017). Customer engagement: the construct, antecedents, and consequences. Journal of the Academy of Marketing Science, 45(3), 294-311. https://doi.org/10.1007/s11747-016-0485-6

Papaioannou, A., Kriemadis, T., Kapetaniou, P., Yfantidou, G., \& Kourtesopoulou, A. (2018). Customer oriented strategy and business performance in tourism and hospitality industry. In Innovative Approaches to Tourism and Leisure (pp. 417-432). Springer, Cham.

https://doi.org/10.1007/978-3-319-67603-6_32

Pires, G., Stanton, J., \& Rita, P. (2006). The internet, consumer empowerment and marketing strategies. European Journal of Marketing, 40(9/10), 936-949.

https://doi.org/10.1108/03090560610680943

Pranic, L., \& Roehl, W. (2012). Rethinking service recovery: A customer empowerment (CE) perspective. Journal of Business Economics and Management, 13(2), 242-260. https://doi.org/10.3846/16111699.2011.620137

Sarkar, A., \& Sreejesh, S. (2014). Examination of the roles played by brand love and jealousy in shaping customer engagement. Jour- nal of Product \& Brand Management, 23(1), 24-32.

https://doi.org/10.1108/JPBM-05-2013-0315

Shankar, A., Cherrier, H., \& Canniford, R. (2006). Consumer empowerment: A Foucauldian interpretation. European Journal of Marketing, 40(9/10), 1013-1030. https://doi.org/10.1108/03090560610680989

Siano, A., Vollero, A., \& Palazzo, M. (2011). Exploring the role of online consumer empowerment in reputation building: research questions and hypotheses. Journal of Brand Management, 19(1), 57-71. https://doi.org/10.1057/bm.2011.23

So, K., King, C., Sparks, B., \& Wang, Y. (2016). The role of customer engagement in building consumer loyalty to tourism brands. Journal of Travel Research, 55(1), 64-78. https://doi.org/10.1177/0047287514541008

Stacciarini, T. S. G., \& Pace, A. E. (2017). Confirmatory factor analysis of the appraisal of self-care agency scale-revised. Revista Latino-Americana de Enfermagem, 25. https://doi.org/10.1590/1518-8345.1378.2856

Taber, K. S. (2018). The use of Cronbach's Alpha when developing and reporting research instruments in science education. Research in Science Education, 48(6), 1273-1296. https://doi.org/10.1007/s11165-016-9602-2

Tsiotsou, R. (2016). The social aspects of consumption as predictors of consumer loyalty: Online vs. offline services. Journal of Service Management, 27(2), 91-116. https://doi.org/10.1108/JOSM-04-2015-0117

Tsiotsou, R. H. (2013). The role of brand relationships and tribal behavior on brand loyalty. In American Marketing Association Winter Educ Conference Proceedings, 24, 366-374.

Van Doorn, J., Lemon, K., Mittal, V., Nass, S., Pick, D., Pirner, P., \& Verhoef, P. (2010). Customer engagement behavior: Theoretical foundations and research directions. Journal of Service Research, 13(3), 253-266. https://doi.org/10.1177/1094670510375599

Vivek, S., Beatty, S., \& Morgan, R. (2012). Customer engagement: Exploring customer relationships beyond purchase. Journal of Marketing Theory and Practice, 20(2), 122-146. https://doi.org/10.2753/MTP1069-6679200201

Walliman, N. (2017). Research methods: The basics (2 ${ }^{\text {nd }}$ ed.). Abingdon, Oxon; New York, NY: Routledge.

Zainudin, M., \& Subali, B. (2019). Construct validity of mathematical creativity instrument: first-order and second-order confirmatory factor analysis. International Journal of Instruction, 12(3), 595-614. https://doi.org/10.29333/iji.2019.12336a 